\title{
Judging By The Methodology Of Learning Islamic Education Which Eroded The Times
}

\author{
Ainun Mardia Harahap ${ }^{1)}$ \\ 1) Jurusan Tarbiyah dan Ilmu Keguruan, Sekolah Tinggi Agama Islam Negeri Mandailing Natal \\ *Coresponding Author \\ Email : ainunmardia1666@gmail.com
}

\begin{abstract}
Learning methodology is part of the set of scientific disciplines that become its parent. Almost all sciences have their own methodologies. Therefore, Islamic education as one of the disciplines has a methodology, namely the method of Islamic education. Islamic education from year to year resulted in many changes in the Islamic world. Both in terms of religion, education, politics and so on. Especially in the field of Islamic education, due to the attitude of the educators who are permissive and indulgent, many children fall into associations that ignore the Shari'ah. Many educators forget their nature as uswahnya students who are obliged to educate students to have good morals. This results in the child's world being in vain. Giving quite a lot of contribution to the futility of the western educational methods that seem to have become the mecca of our education. So that every educator uses more general education methods, even the methods used in their learning programs are by using the lecture method, question and answer, discussion, demonstrators, and so on. This naturally erodes the understanding of educators and students on Islamic education methods. Actually Islam has a perfect education method for mankind, especially in the field of Islamic education. Therefore, educators return to their hittah, namely mastering Islamic education methods, so that the function of Islamic Education Methods will later help realize and carry out the goals of education itself.
\end{abstract}

Keywords: Teaching Methodology, Islamic Education, The Development Of The Times

\section{INTRODUCTION}

It is no exaggeration if there is a phrase "aththariqah ahammu minal maddah", that method is far more important than the material, because as good as any educational purpose, if not supported by appropriate methods, such goal is very difficult to be achieved with good. A method will affect up tidaknyasuatu the information is complete or not. Therefore, the selection of the methods of education must be done carefully, customized with a variety of related factors, so that the results of education can memuasakan. What the Messenger of allah SWT when delivering the revelation of God to his companions we can look up, because the Messenger of allah peace be upon Him.

Since the beginning of the already implemented methods appropriate education toward his companions. Learning strategies what he's doing is very accurate in conveying the teachings of Islam. The messenger of allah peace be upon him, very attentive to the situation, the conditions and character of a person, so that islamic values can be transferred with good. The messenger of allah peace be upon him. Also very understanding of the instincts and the conditions of each people, so he was able to make them like the mind, both material and spiritual, he always invites people to approach almighty God, and shari'ah-His. 


\section{RESEARCH METHODS}

Methods the study is a review of the literature or literary studies, which contains theories that are relevant to the research problem. The problem in this research is to survey the methods of islamic learning are eroded by the development of the era. In this section, the concept and the theory used is made based on the available literature, mainly from articles published in various scientific journals. A literature review serves to build the concept or theory that forms the basis of the study in research. Literature review or literature study is an activity that is required in research, especially academic research main objective is to develop the theoretical aspects as well as aspects of the practical benefits.

\section{RESULTS AND DISCUSSION}

\section{Methods Of Islamic Education}

\section{Methods example}

One thing is undeniable that children tend to love and love to imitate the behavior of teachers/educators. In the Qur'an the word exemplary is equated in the word uswah which is then given of the properties behind it such as the properties hasanah which means good.so it can be brought into uswatun hasanah which means a good example. Said the following in the Quran is repeated six times by taking the example of the Messenger of allah peace be upon HIM, Prophet Ibrahim and the people who believe firmly in God, the Word of Allah SWT in surah al-Ahzab: 21

Meaning: there is Indeed in (self -) the Messenger a good example for you (ie) for anyone whose hope is in (mercy) of God and the (coming) judgment day and remembers Allah much.

\section{The method of habituation}

In the formation of attitudes, the methods of habituation is actually quite effective, people are regular clean will choose to live clean is not only physical, but can have an impact against a clean mind and heart. Need dingat that habituation cored repetition, then the method of habituation is also useful to strengthen the mnemonics, the Messenger of allah repeatedly pray with prayer the same, then Raulullah memorized do'anya it.

\section{Methods advice}

The qur'an also uses sentences that touch the heart to direct people to the idea that he wants. This is then known advice. But in any advice he said it's always with the example of 1 of the giver or the delivery of that advice. This suggests that between one method, namely advice with other methods, which in this example is complete. In the Qur'an, the words that explain about the advice is repeated 13 times in 13 verses in the seven letters. Among the verses related to the Prophet Salehkepada his people, in the word of Allah in surah al-Araf ayat 79.

Meaning: So Salih left them, saying: "O my people! Verily I have delivered unto you the mandate of the Lord, and I have given you advice, but you don't like people who give advice".

\section{Methods Of Stories}

In the qur'an in addition there is the name of the letter, namely surah al-Qasash which means stories or stories, also said that the story be repeated as much as 44 times. According to the Quraish Shihab that in revealed the story in the qur'an did not hesitate to tell the "human weakness". However, it is digambarkanya as is, without highlight the aspects that can invite the stimuli. The tale usually ends with the underlined due to the weakness of it, or to depict the current awareness and victory defeat the weakness of the last. 


\section{Methods Hiwar (Dialogue or Conversation)}

The method of the dialog is the method that is based on dialogue, a conversation through tanyak responsible for up to the fact yant can not be doubted, criticized, and it takes longer. And pendialog usually through three stages bang won in a row; first through a stage of belief that has no basis, and the task pendialog at this stage is manifest folly of people to whom they are in dialogue, also shows the kecongkangan and vanity are unfounded and she also received the opinions of others without based on logic. The second stage is the stage with confidence where people are invited to a dialogue without hesitation, the establishment and the words is not fixed and it seems to be the attitude of jongkolnya, the third stage is the stage of belief after with confidence or stage based on the consciousness or not based on the persecution blindly.

\section{Methods Kisasi (Al-qur'an and Nabawi)}

Methods kisasi (the story of, well kisasi the qur'an and kisasi Nabawi, both stressed and the narrative about the stories that are contained in the Qur'an, and which is based on the seerah of the Prophet. And the application of the method kisasi this as a learning method in the field of Islamic education study contain a high educational value, a story is always alluring and inviting the reader or listener to follow the event and reflect on its meaning and the story can also touch the hearts of men because of the display of the figures in the context of a thorough, so that the listener or reader can come to appreciate and feel the contents of the story it was as if he himself be pelakonnya. The story can educate the feeling of faith with terbangkitnya a variety of feelings such as atf, pleasure, love and defeat the whole feeling so shed on a peak that is the conclusion of the story, as well as involving the reader or listener into the story that he was emotionally involved.

\section{The method of Proverbs (parables)}

Parables in the Qur'an (Q.S 2:17 and Q.S 29:41) can be and is often used ustadz lecturer in the study-recitation and majelis taklim and disclosure of which is almost the same with the method of the story with a lecture or reading a text. The goodness of this method is seen from several aspects, namely strengthening the participants of the study (jama'ah) using the concept that the abstract can be a stimulating impression of the meaning that is used in teaching, usually the imagery used are logical so easy to understood, A parable-the qur'an and the Prophet gives motivation to the listener or jamaah majelis taklim to do good deeds and stay away from evil this is the important in Islamic education.

\section{Method Al-Ibrah Wa Al-Mau'izah}

Islamic education gives special to the method of Al-Tribulations (I'tibar) so that learners can take the stories in the Qur'an and hadith as well as the figures of the al-salaf al-salih not be of one mind,-said aspects of its historical course, but the important lessons contained in it as something valuable to be accomplished in everyday life.

While the method Mau'izah (teaching through counsel) is a method that is effective enough to touch the hearts and feelings due to the method of Mau'izah is basically the minds and feelings of the learners directly. This method can be applied through a variety of subjects through the content of the values contained in it.

\section{The method Al-Targhib Wa Al-Tarhib}

This method is based on the nature of man who wants happiness pleasure and safety and do not want pain and misery. This method is a method mainstay in the education of Islam who do not want the existence of punishment and reward, except in the context of as the only way that can be taken. And the application of this method is almost similar to the method Mau'izah, but penekananya is to provide an overview of rational touching the thoughts and feelings of the learners that anyone who do good will gain the reward of an abundant reward from Allah, on the contrary who accept the risk of non peduliannya in carrying out the goodness and truth dictated by God. 


\section{The method Islamic education eroded Methods General Education}

Method-the method of general education in school gives more freedom to the citizens learn to develop their interests and talents in a short time. Methods-this method is also adapted to the situation and conditions encountered such a situation and the condition number, age, gender, status, interests, as well as the time, place, facilities and funds available for the program.

There are several methods that are often used in teaching in schools, among others, that

\section{Lecture Method}

Teachers provide a description or an explanation to a number of students at a specific time (time is limited) and a specific place anyway. Implemented with the language lisanuntuk provide an understanding of something is a problem, because it is the way it is often also called by the lecture method, because there are similarities teacher with a professor/master teacher giving a lecture to students.

\section{Discussion Method}

This method is usually closely related to the other methods, for example methods lectures, rich travel, and others due to the method of this discussion is the most important part in solving the issue something (problem solving).

\section{Methods Experiments}

This method is usually done in a certain subjects such as natural science, chemistry, and so forth, usually against science-ilmualam in research using methods that are objective, well done on the inside/ outside of the classroom or in a laboratory specific.

\section{Demonstration Method}

A method demonstration is a teaching method that uses the show to clarify an understanding or to demonstrate how to do something teachers do it themselves or by their students.

With the method of the demonstration of the teacher or the students showed to all members of the class present something of the process, for example the image of prayer in accordance with the teachings of the Prophet muhammad. Then shown images of people of prayer in accordance with the teachings of islam.

\section{The Method Of Administration Tasks}

What is meant by this method is a way in the teaching and learning process where the teacher gives specific task and pupils get to it, then the task is accountable to the teacher. By this way, it is expected that students learn freely but responsibly and the disciples will be experienced to know the various difficulties then trying to help overcome these problems.

\section{Methods Sosiodrama}

Plays or skits carried out by a group of people, to play a story that has been prepared the manuscript of the story and studied before it is played. As for the culprit must understand first about the role each of which shall be delivered to.

\section{Drill Method}

The use of the term "exercise" is often equated that with the term "replay". Though the meaning is different. The exercise intends that the knowledge and skills specific can be the property protege and is fully controlled, while the replay just to simply measure the extent to which he has absorbed the lessons of the.

\section{The Method Of Group Work}

What if the teachers in the face of the students in the class feel the need to divide the students to solve a problem or to submit a job that needs to be done together, then how to teach the method can be used group work. 


\section{The Method Of Question And Answer}

Is one of teaching techniques that can help the shortage on lecture method. This is caused because the teacher can obtain a picture of the extent to which the students can understand and can express what has been diceramahkan.

\section{Project Method}

This method is also called engineering teaching unit. The students were treated to an assortment of the problem by following certain steps in a scientific, logical and systematic. This way is a technique that modren, because students can't just.

\section{Discussion}

\section{a. Judging By The Use Of The Method Of Learning}

As a science Methodology or Method is part of the scientific disciplines that be a parent. Almost all science has a methodology of its own. Therefore, Islamic Education as one of the disciplines have the methodology is the method of Islamic Education, which is a science about methods used in the work of educating.

Islamic education is a very important thing for a person's life, because with Islamic education one can achieve the desired goals as well as being a man who has morals and behavior. Of course to achieve the ideals of such a person needs professional educators to help realize these ideals.

Because educators are the main key in achieving the goal desired by everyone, so in this case educators have to work hard for it. That hard work should be supported by the competence possessed by an educator. If an educator does not have competence in the field of methods of Islamic education, it can be ascertained learners will not be able to achieve his ideals, as well as with the world of Islamic education will not achieve the expected goal, namely to make the learners be insan kamil.Surely an educator must have a method or a way to realize it all. Educators must be prepared so uswatun hasanah, have hiwar good, good habits, the ability to advise, take a good lesson from any problems that exist, and the ability of reward whether in the form of reward or punishment.

Nowadays the growing world of Islamic education from year-to year changes in the Islamic world. In terms of religion, education, politics and so on. Especially in the field of Islamic education, due to the attitude of educators versatile and indulgence, a lot of children falling on the promiscuity of the neglect of the shari'ah. Many educators forget about his nature as a uswahnya learners are obliged to educate learners to have akhlakul karimah. Resulting in the child's world in vain. The provision contributed quite a lot in the futility of such is the method of western education which seems to have become a mecca of our education. So each of educators more using the method of general education, even the methods used in the program of learning is by using the lecture method, question and answer, discussion, protesters, and others. By itself it is this that scrape the understanding of educators and learners on the methods of Islamic education. Actually Islam has a method of education that are perfect to mankind, especially in the field of Islamic education. Therefore, educators back to hittahnya, namely master the methods of Islamic education, so that the function of the Methods of Islamic Education that will help realize and implementation of the objectives of the education itself. 


\section{CONCLUSION}

Based on the discussion about Judging the Methodology of Learning Islamic Education which Eroded the Development of the Times above, it can be concluded, among other things:

1. Methods of learning here interpreted as a series of considerations, decisions, and actions associated with the approach, strategy, and the specific techniques need to be selected and used to optimize the achievement of learning goals.

2. An educator in a school need to estimate that to reach a goal, specific learning optimally needed approaches, strategies, and techniques of learning anything. Furthermore, after implementing the decision of education conduct an evaluation of the effectiveness, efficiency, and appeal of such methods.

3. Every educator in the school are required to have some strategic abilities. Among these is the extensive knowledge, reasoning that strong, initiative-rich, creativity, adequate, and high flexibility in identifying, choosing, and using the method of learning as well as develop it further. These capabilities even need to be continuously updated and developed so as not to have lag with the progress of science and technology that continues to grow. This also is in accordance with the principle of lifelong learning, the principle of which becomes the handle acts every educator in the school.

\section{REFERENCES}

Abdul Mujib dan Jusuf Mudzakkir. Ilmu Pendidikan Islam, Jakarta: Kencana Prenada Media, 2010.

Abuddin Nata, perspektif Islam tentang Strategi Pembelajaran, Jakarta: Kencana Prenada Media Group, 2011.

Asmadawati, Desain Pembelajaran Agama Islam, Padang: Rios Multicipta, 2013.

Dja'far Siddik, Konsep Dasar Ilmu Pendidikan Islam, Bandung: Cita Pustaka Media, 2006.

Muhammad Fuad Abd al-Baqy, Al-Mu'jam al-Mufrasdli Alfazharl Qur'an al-Karim, Solo: Dar al-Fikr, 1987.

Zakiah Daradjat, et.all., Metodik Khusus Pengajaran Agama Islam, Jakarta: Bumi Aksara, 2001. 